НИКОЛАЕВ Иван Романович преподаватель-исследователь, руководитель отдела морского, речного и подводного культурного наследия Культурно-исторического центра «Светоч», Москва, Российская Федерация Ivan R. NIKOLAEV Lecturer-Researcher, Cultural and Historical Center "Svetoch", Moscow, Russian Federation, i.nikolaev.phd@yandex.ru ORCID: 0000-0002-5438-8835

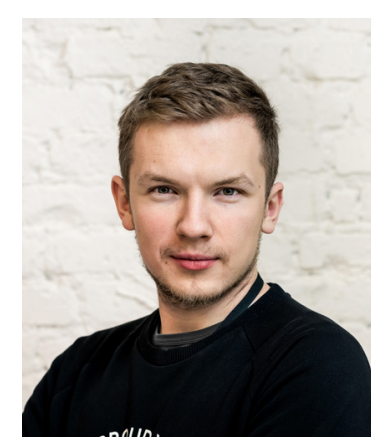

УДК 351.853:656.61(410)

\section{Морское культурное наследие: история становления и развития понятия на примере Великобритании}

\author{
Maritime Cultural Heritage: \\ The History of the Formation \\ and Development of the Concept \\ on the Example of Great Britain
}

Статья посвящена исследованию истории формирования и функционирования понятия «морское и подводное культурное наследие», а также анализу эволюции ценностей, вкладываемых в объекты наследия, связанные с морской культурой. Цель работы - определение этапов системного научного осмысления морского и подводного культурного наследия в Великобритании и процесса становления соответствующего понятия. Базой для научных изысканий автора явились исследования британских ученых, охватывающие период с середины XVII в. по настоящее время. В ходе исследования выделены три основных периода в истории формирования представлений о морском культурном наследии Великобритании, предложен вариант трактовки рассматриваемого понятия, которое определяется как совокупность объектов материального и нематериального культурного наследия, связанных со всеми аспектами мореплавания и освоения человеком водных пространств.

Ключевые слова: морское наследие, подводное культурное наследие, Великобритания, морская культура, кораблекрушение, палеоландшафт, Кит Макелрой, морская археология.

Морское и подводное культурное наследие (далее - МПКН) - предмет активных научных дискуссий в современном мире, особенно в последние десятилетия. В связи с очевидной необходимостью изучения и сохранения
МПКН как части всемирного наследия возник общественный и государственный запрос на формирование подходов к управлению наследием, подготовку профильных специалистов в этой области. Разработка программ 
подготовки международного уровня требует изучения зарубежного опыта.

Великобритания - страна с многовековой морской культурой и значительным вкладом в формирование подходов к изучению и сохранению МПКН. В англоязычной научной среде подводное культурное наследие включают в понятие «Maritime heritage», переводимое на русский язык как «морское наследие». Подобный прямой перевод нельзя назвать полностью верным, так как слово «maritime» означает «морской», «судовой», «относящийся к морю». В связи с этим к «маритимному» наследию относят объекты, находящиеся в морях, реках и иных водоемах, на их побережье, а также нематериальное культурное наследие, связанное с освоением человеком водных пространств. В связи с этим далее в работе понятие «Maritime heritage» будет употребляться как «морское культурное наследие» и применяться в комплексе МПКН.

Морское культурное наследие в Великобритании не имеет однозначного или утвержденного законом определения, но активно используется в научной среде. К этому понятию обращаются преимущественно для интерпретации объектов под водой, но с учетом их морского контекста. История изучения МПКН в Великобритании представляет особенный интерес, так как британская практика изучения МПКН развивалась совместно с европейской (и с практикой стран европейского типа).

Исследование этого вопроса имеет теоретическую значимость применительно к формированию знаний об истории изучения МПКН в мире. Практическое применение данная работа может найти в ходе разработки рабочих программ дисциплин, связанных с изучением морского наследия и культурного наследия в целом, при подготовке специалистов в области культурологии, археологии, музеологии.

Цель исследования - определение основных этапов становления научного взгляда на изучение МПКН в Великобритании и формирование понятия, способного комплексно охарактеризовать его. Задачи - выявление причин применения понятия «морское культурное наследие» взамен подводного и анализ процесса вовлечения в исследования зато- пленных объектов аспектов, связанных с изучением наземного, нематериального и иного морского культурного наследия, не погруженного под воду. Характер исследования обусловил применения исторического подхода и, в частности, историко-генетического и историко-системного методов.

Вопрос истории формирования взглядов на МПКН как на отдельную часть культурного наследия исследователи ранее не поднимали. Существующие работы рассматривают историю археологических исследований, особое внимание уделяя морской или подводной археологии. Крупнейшие статьи, посвященные истории международных археологических исследований за рубежом написаны пионером подводной археологии Джорджем Бассом [4] и американским исследователем Чарльзом Мейде [29]. Аналогичное исследование в отношении отечественной подводной археологии проводил А.В. Окороков [2]. Автор подробно рассмотрел наиболее важные вехи в становлении гидроархеологии в России, описав знаковые находки и археологические экспедиции, выделив ключевые персоналии.

Первые исследования объектов наследия под водой стоит рассматривать со второй половины XVII в., в разгар эпохи антикварианизма. Находки редко вызывали исследовательский интерес и предполагали извлечение финансовой выгоды из найденного. Яркий пример - деятельность сэра Уильяма Фиппса, мореплавателя, который прославился как охотник за сокровищами «постоянно находящий затонувшие корабли [17, р. 125]». Основные поиски капитан вел в Карибском бассейне, начиная с 1643 г. В 1687 г. он нашел затонувшее судно испанского серебряного флота «Нуэстра Сеньора де ла Консепсьон». Общий вес найденных ценностей превысил 34 тонны, что было эквивалентно 205536 фунтов стерлингов [17, p. 201].

Возможность обогатиться долгое время была основным импульсом к поиску культурного наследия под водой. Одним из ключевых событий для истории изучения МПКН в Великобритании стало обнаружение рыбаками из Солента в 1836 году потерпевшего крушение корабля. Судно идентифицировали как «Мэри Роуз» в начале августа того же года 
[35, p. 556]. Раскопки во многом стали грабительскими, однако нанятые водолазы Джон и Чарльз Дин заказали акварельные рисунки предметов, добытых с корабля, что определяется британскими исследователями как момент возникновения интереса к исторической ценности предмета [6, p. 108-118; 24, p. 26-29]. Развитие исторического интереса к МПКН выделяется в работах второй половины XIX - начала XX в. В этот период концепция морского культурного наследия ещё не сформировалась, но исследователями был написан ряд знаковых работ, посвященных его объектам. Приоритет оставался за кораблями и историей судостроения.

В 1874 г. этнограф и археолог Огастес Питт Риверс написал большую статью «Ранние способы навигации» [37], в которой рассматривал методы судостроения и судоходства древних Австралии и Тасмании. В 1895 году британский археолог Сесил Торр посвятил кораблям Средиземноморья монографию «Древние корабли» [42]. Одной из наиболее всеобъемлющих можно считать работу английского ученого Джеймса Хорнелла «Водный транспорт: происхождение и эволюция», посвященную возникновению плавательных средств и их развитию в целом [22].

Набирающей интерес темой стало изучение палеоландшафтов. Британские исследователи одними из первых в мире обратили внимание на необходимость изучения доисторических останков на дне, однако издаваемые научные работы не вызывали интереса широких масс.

В 1839 г. английский геолог Генри де ла Беш впервые описал видимую часть затопленного леса у берегов западного Сомерсета. Его исследование развил Роберт Годвин-Остин в 1865 г., выступив с докладом о результатах в Лондонском Геологическом Обществе [16, pp. 141-142]. Одной из наиболее ценных находок для того времени стало обнаружение Уильямом Бойдом-Докинсом остатков кремня со следами обработки человеком в 1861 и 1869 гг. [16, р. 142]. Находка подтвердила представления ученых о прежней обитаемости затопленной ныне суши, однако в широком научном поле не снискала популярности.
Начало XX в. выделяется рядом научных работ, признанно оказавших влияние на дальнейшее развитие изучения палеоландшафтов. В 1913 г. палеобиолог Клемент Рид издал научную работу «Затопленные леса», в которой говорил о существовании затонувшего сухопутного моста между восточной Англией и материковой Европой и даже изобразил на концептуальной карте границы, схожие с выделяемыми сейчас [39, p. 40]. В 1927 году в учреждавшемся тогда журнале «Античность» была опубликована статья Осберта Кроуфорда, посвященная затопленным доисторическим ландшафтам. Сам автор выразил надежду на дальнейшее развитие темы и увеличение внимания к направлению в целом [15, p. 14].

1930-е гг. можно назвать поворотными. В 1931 г. в районе Доггер-банки обнаружили рыболовный гарпун эпохи мезолита в сорока километрах от ближайшего берега [9], что стало уверенным указанием на необходимость изучать доисторические ландшафты на дне. Эта находка повлияла на последующие крупные публикации пионеров изучения палеоистории - Гарри Годвина и Грэхема Кларка. Оба автора опирались на работу Рида. В 1932м они приняли активное участие в формировании Исследовательского комитета Фенленда в и в составе этого объединения провели исследования региона [12]. В дальнейшем оба исследователя продолжили свою работу как по одиночке [13; 20], так и совместно, на комплексе Стар-Карр [18].

Примечательным становится тот факт, что не только академические исследователи меняют привычный взгляд на подводные археологические находки. В 1909-1910-х гг. шотландский монах Одо Бланделл провел исследования доисторических свайных поселений, называемых кранногами. Целью погружений было изучение истории Шотландии и строительных подходов. Бланделл зарисовал чертежи затопленных частей построек и впоследствии сообщал о своих находках [7; 8]. В 1910 г. журналист и отставной командующий флотом Чарльз Нейпир Робинсон основал Общество морских исследований (Society for Nautical Research), нацеленное на изучение и сохранение морской истории [34]. В 1911 г. образован- 
ное общество начало выпускать академический журнал «Зеркало моряка» (The Mariner's mirror), являющийся одним из самых старых научных изданий, посвященных вопросам морской и военно-морской истории, и публикуемый по сей день.

В 1937 г. энтузиасты Тед и Вильям Райт обнаружили останки лодки на берегах реки Хамбер на северо-востоке Англии. Братья Райт не были археологами, но осознавали историческую и исследовательскую ценность находки, в дальнейшем участвуя в раскопках [45; 46].

Изобретение акваланга Эмилем Ганьяном и Жаком-Ивом Кусто в 1942-1943 гг., сделало подводный мир доступнее, привело к возникновению ряда пионерных исследований в области подводной археологии, но общие взгляды на значение морского и подводного культурного наследия разительно не изменились.

Среди известных британских пионеров подводной археологии следует отметить Хонор Фрост, киприотку, изучавшую археологию в Лондоне. Её первые исследования проходили в 1959 г. совместно с Фредериком Дюма, одним из дайверов Кусто, а также с американским журналистом и археологом Питером Трокмортоном вблизи мыса Гелидония в Турции [36, p. 235].

Позднее Хонор Фрост предложила стать содиректором раскопок шотландской исследовательнице Джоан дю Плат Тейлор, которую встретила в Институте археологии в Лондоне, а Трокмортон привлек еще одного американского исследователя, на тот момент аспиранта,- Джорджа Басса. Раскопки у мыса Гелидония стали одним из первых прецедентов, когда археологи обучались дайвингу, а не были дайверами, проводящими работу по инструкции с поверхности [5].

Внимание к изучению кораблекрушений достигло пика во второй половине XX в., благодаря обнаружению останков Непобедимой армады у берегов Ирландии и Шотландии в конце 60-х гг. В 1967 г. бельгиец Робер Стенюи нашел галеас «Хирона» у графства Антрим в Северной Ирландии [41]. В 1968 г., валиец Сидней Вигнал нашел корабль «Санта Мария де ла Роса» рядом с островами Бласкет
[25]. Корабль «Ла Тринидад Валенсера» был обнаружен близ Киннаго Бэй группой спортивных дайверов во главе с шотландцем Колином Мартином в 1971 г. [26; 27]. Интерес же к подводной палеоистории в районе Северного моря, поддерживаемый, в основном, Кларком и Годвином, напротив, значительно снизился.

Исследователь Джонатан Адамс отмечает, что в 1970-е годы подводная археология уже была популярна, «однако новое направление часто интерпретировалось как нечто ненаучное, в больщей степени связанное с охотой на сокровища» [3, p. 8]. Большинство исследователей того времени, несмотря на выраженный интерес к исследованиям, не имели профильного образования. Из двадцати одного автора в изданной в 1972 г. работы «Археология под водой: зарождающаяся дисциплина» больше пятнадцати не были археологами [20; 43].

Зарождение дисциплины и самостоятельного научного направления требовало как создания методологии касательно планирования и проведения исследований, так и общетеоретических работ, призванных сформировать академический понятийный аппарат.

Прорывной и новаторский взгляд на исследовательские подходы внёс шотландец Кит Макелрой [22]. Большое влияние на его работу оказали взгляды британских археологов Грэма Кларка и Дэвида Кларка, у которых он учился в Кембридже. Под влиянием изученных принципов доисторической, аналитической, горячо обсуждаемой в то время процессуальной археологии и собственного исследовательского опыта Макелрой написал ряд теоретических трудов в области морской археологии [29-33].

В 1976 г. он опубликовал статью о процессах формирования археологического памятника. В ней он предложил первую систематическую модель для характеристики и интерпретации археологии кораблекрушений [33].Модель, переведенная на русский язык, представлена на рисунке 1.

По мысли Макелроя, для интерпретации судна в его изначальном социально-культурном контексте требуется трехчастная система:

- корабль как машина, предназначенная для использования в качестве транспортного средства; 


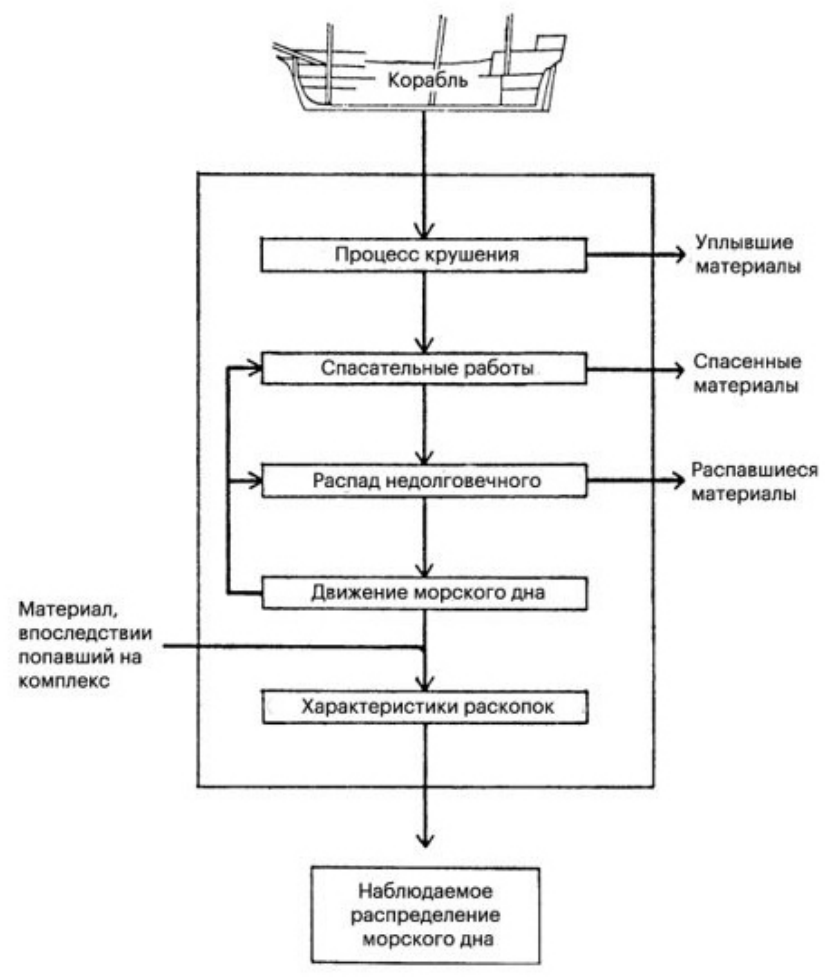

Рис. 1. Блок-схема, отражающая развитие комплекса кораблекрушения. Кит Макелрой, 1978 [33, р. 282]

- корабль как элемент военной или экономической системы;

- корабль как закрытое сообщество, со своей иерархией, обычаями и культурой [32, p. 216].

Труды Макелроя отражают переход от изучения кораблей к изучению людей и культур, строящих корабли. Центральным результатом его работы становится монография «Морская археология», вводящая термин «Maritime archaeology», определяющийся следующим образом: «Морская археология - это научное изучение, посредством сохранившихся материальных свидетельств, всех аспектов мореплавания: судов, лодок и их оборудования; грузов, уловов или пассажиров, перевозимых на них, и экономических систем, в рамках которых они действовали; их офицеров и членов экипажа, особенно посуды и другого имущества, отражающего их специализированный образ жизни» [32, р. 6].

Преждевременная смерть Кита Макелроя в 1980 г. не позволила ему полностью раскрыть свои идеи, но реализованная часть продвинула как подводно-археологические исследования, так и изучение морского культурного наследия. Смещение фокуса внимания с затопленных объектов на сопутствующую им культуру позволила охватить объекты наследия, находящиеся на поверхности и связанные общим контекстом. То есть с нарочито подводного внимание перешло к более широкому - морскому.

Контекстуализация и нарастание символизма в изучении морского наследия проходило следом за этими же процессами в наземной археологии, сформировав новые течения в морских и подводных исследованиях в 1980-х гг. Среди них концепция прибрежного культурного ландшафта, предложенная Кристером Вестердалем в Скандинавии [44], постпроцессуальное течение в наземной археологии, основанное Иэном Ходдером в Великобритании [21].

Эти движения усиливаются к 1990-м гг. В морские исследования начинают проникать подходы, направленные на критический анализ современности. В 1995 г. Энтони Ферт опубликовал в Интернете документ под названием «Теоретические достижения в морской археологии», представленный ранее на конференции Группы теоретической археологии (TAG) в Дареме [19]. Ферт стал одним из первых, кто обратился к морским археологам с призывом критически рассмотреть такие вопросы, как колониализм, консумеризм, капитализм и современность, приобретавшие все большее значение для исторической археологии. Среди актуальных критических тем, изучаемых в настоящее время, стоит отметить исследования посвященные тематике гендерности, роли ЛГБТ в морской истории [38; 40].

Наконец, значительное влияние на представления о морском и подводном культурном наследии оказали международные дискуссии, поднимающие вопросы сохранения наследия. 
Термин «подводное культурное наследие» впервые прозвучал в Софийской хартии ИКОMOC 1996 г. [11, р. 122], где стал развитием термина «археологическое наследие» из Лозаннской хартии ИКОМОС 1990 г., которое характеризует «все следы человеческого обитания и состоит из мест, фиксирующих все проявления деятельности человека, в том числе покинутых строений и руин всех видов (включая подземные и подводные) вместе со всем подъёмным культурным материалом» [10, р. 104].

Широкое распространение и развитие «подводного культурного наследия» как понятия принесла Конвенция ЮНЕСКО 2001 г. «Об охране подводного культурного наследия». Она оказала большое влияние на развитие подходов к защите подводного культурного наследия, повысила уровень осведомленности общественности и продвигает идею международного сотрудничества [1, с. 56-57].

Определение морского наследия как научного понятия в Великобритании не сформировано, несмотря на регулярное применение в научных работах. Историческая Англия, вневедомственный государственный орган, работающий в сфере сохранения национального наследия, разделяет понятия морского и подводного наследия, в то же время понимая под морским - подводное культурное наследие.

В качестве морского наследия применяют определение, данное Софийской хартией ИКОМОС: «Под подводным культурным наследием понимается археологическое наследие, которое находится в подводной среде или удалено из нее. Оно включает затопленные участки и сооружения, места крушения и обломки, а также их археологический и природный контекст» [11, р. 122].

Под подводным культурным наследием понимают определенное Конвенцией 2001 г. значение: «все следы человеческого существования, имеющие культурный, исторический или археологический характер, которые частично или полностью, периодически или постоянно находятся под водой на протяжении не менее 100 лет, такие, как: і) объекты, сооружения, здания, артефакты и человеческие останки вместе с их археологическим и природным окружением; іi) суда, летательные аппараты, другие транспортные средства или любые их части, их груз или другое содержимое, вместе с их археологическим и природным окружением; и іiі) предметы доисторического характера» [14, р. 1-2].

Иная позиция выражена в одном из докладов Комитета по культуре, СМИ и спорту Палате общин. В 2004-2005 гг. одними из центральных вопросов, стоявших перед Комитетом, были морское наследие и исторические корабли. Доклад не дает определения морскому наследию, но отмечает, что сотрудники «сосредоточили наши исследования на надводных, исторических судах и рассматривали их как музеи и / или экспонаты, а не как археологические памятники» [23, p. 4], что также указывает на преимущественную подводно-археологическую трактовку понятия.

Рассмотренные позиции не противоречат пониманию морского культурного наследия исследователями, но отражают лишь часть, связанную с материальными аспектами, в частности, флотскими. Научные работы расширяют понятие, уделяя внимание нематериальным аспектам наследия, морской культуре и истории практик освоения человеком водных пространств.

Процесс формирования представлений о морском культурном наследии позволяет выделить три периода в его истории. Первый период (вторая половина XVII в.- 1836 г.) отличается преимущественно коммерческой интерпретацией объектов наследия, свойственной эпохе антикварианизма. Второй период (1836 г.-1976 г.) отражает развитие интереса к изучению исторических аспектов наследия, плодотворных, но бессистемных. Третий период (1976 г.- настоящее время) выделяется возникновением и развитием методов изучения МПКН, контекстуализацией, отмечает необходимость изучения морской культуры для понимания подводного культурного наследия.

Наиболее важное изменение в интерпретации МПКН - смещение центра внимания с предмета на человека и культуру, к которой принадлежит предмет. Это же обусловило переход от исключительно подводного к морскому, «маритимному», культурному наследию. Основываясь на выявленной истории формирования понятия и его текущем смысловом наполнении, возможно определе- 
ние морского культурного наследия как совокупности объектов материального и нематериального культурного наследия, связанных со всеми аспектами мореплавания и освоения человеком водных пространств.

Основное направление дальнейших исследований в отношении истории изучения МПКН подразумевает раскрытие национального опыта иных государств, в особенности относящихся к романским странам, странам Восточной Европы, Ближнего Востока,
Азии и др. Интерпретация морского культурного наследия в большинстве стран европейского типа схожа, так как развитие научного направления включало тесные контакты между исследователями разных стран, а также присутствие британских ученых за пределами государства, в частности, на Средиземном море [4; 5; 30]. В то же время практика азиатских и африканских стран во многом является «белым пятном» в истории изучения МПКН.

\section{Ivan R. NIKOLAEV \\ Lecturer-Researcher, Cultural and Historical Center "Svetoch", Moscow, Russian Federation, i.nikolaev.phd@yandex.ru}

\section{Maritime Cultural Heritage: The History of the Formation and Development of the Concept on the Example of Great Britain}

Abstract. The article is devoted to the study of the history of the formation and functioning of the concept "maritime and underwater cultural heritage", as well as to the analysis of the evolution of values invested in heritage objects related to maritime culture. The study is based on materials reflecting the history of the study of maritime heritage in the UK. The aim of the work is to determine the stages in the formation of a systematic scientific understanding of the maritime and underwater cultural heritage in the UK and the process of establishing the corresponding scientific concept. The basis for the author's research was the study of British scientists, covering the period from the mid17 th century until now. The main attention is paid to underwater cultural heritage as one of the main components of maritime heritage. The author identifies three main periods in the history of the formation of ideas about the maritime cultural heritage of Great Britain. The middle of the 17th century was taken as a starting point, which was the heyday of the era of antiquarianism. Thanks to the active colonial policy and the wars accompanying it, many ships were wrecked, and subsequently a large number of sailors searched for sunken treasures. The reason for this search was by no means a desire to preserve history, but a commercial gain. The milestone that determined the emergence of historical interest in maritime heritage sites is 1836: the year the ship Mary Rose was discovered. The subsequent period (up to the second half of the 20th century) is characterized by the development of historical research in relation to the underwater cultural heritage, but without a sound scientific-methodological component. The third period begins in 1976 after a publication of Keith Muckelroy, a maritime archaeologist, about the formation of an underwater archaeological complex, and after further developments, including the creation of the term "maritime archaeology". The development of the methodology, the conceptualization and updating of critical approaches to historical phenomena have led to the formation of a modern scientific view on the problems of interpretation of maritime cultural heritage. The revealed characteristics of the analyzed concept allowed the author to propose a version of its interpretation, characteristic of European countries. Maritime cultural heritage is defined as a combination of objects of tangible and intangible cultural heritage associated with all aspects of navigation and human development of water spaces.

Keywords: maritime heritage, underwater cultural heritage, United Kingdom, maritime culture, shipwreck, paleolandscape, Keith Muckelroy, maritime archaeology. 


\section{Использованная литература:}

1. Акты Генеральной конференции, 31-я сессия, Париж, 15 октября - 13 ноября 2001 г. Париж: Организация Объединенных Наций, 2002. Т. 1.

2. Окороков А. В. История отечественной подводной археологии. М.: КНОРУС, 2008.

3. Adams J. Ships, Innovation and Social Change: Aspects of Carvel Shipbuilding in Northern Europe 14501850. Stockholm: University of Stockholm, 2003.

4. Bass G. F. The Development of Maritime Archaeology // The Oxford Handbook of Maritime Archaeology. Oxford: Oxford University Press, 2011, pp. 3-24.

5. Bass G. F., Throckmorton P., Du Plat Taylor J., Hennessy J. B., Shulman A. R., Buchholz H. Cape Gelidonya: A Bronze Age Shipwreck // Transactions of the American Philosophical Society, 1967, vol. 57(8), pp. 1-177.

6. Bevan J. The Infernal Diver: The Lives of John and Charles Deane, Their Invention of the Diving Helmet, and Its First Application to Salvage, Treasure Hunting, Civil Engineering and Military Uses. London: Submex, 1996.

7. Blundell F. O. Further Examination of Artificial Islands // Proceedings of the Society of Antiquaries of Scotland, 1910, vol. 44, pp. 12-33.

8. Blundell F. O. Notices of the examination by means of a diving dress of the artificial island or crannog of Eilean Muireach in the south end of Loch Ness // Proceedings of the Society of Antiquaries of Scotland, 1909, vol. 43, pp. 159164.

9. Burkitt M. C. A Maglemose Harpoon dredged up recently from the North Sea // Man, 1932, vol. 32, p. 118.

10. Charter for the Protection and Management of the Archaeological Heritage (1990) // International Charters for Conservation and Restoration. München: Lipp GmbH, 2004, vol. 1, pp. 104-107.

11. Charter on the Protection and Management of Underwater Cultural Heritage (1996) // International Charters for Conservation and Restoration. München: Lipp GmbH, 2004, vol. 1, pp. 122-125.

12. Clark J. G. D. The Mesolithic Age in Britain. Cambridge: Cambridge University Press, 1932.

13. Clark J. G. D. The Mesolithic Settlement of Northern Europe. Cambridge: Cambridge University Press, 1936.

14. Convention on the Protection of the Underwater Cultural Heritage. Paris: UNESCO, 2001.

15. Crawford O. G. S. Lyonesse // Antiquity, 1927, vol. 1(01), pp. 5-14.

16. Dawkins W. B. On the Discovery of Flint and Chert under a Submerged Forest in West Somerset // The Journal of the Ethnological Society of London, 1870, vol. 2, pp. 141146.

17. Earle P. The treasure of the Concepción. New York: Viking Press, 1980.

18. Fagan B. M. Grahame Clark: an intellectual life of an archaeologist. Boulder, Colo.: Westview Press, 2001.

19. Firth A. Three Facets of Maritime Archaeology: Society, Landscape, and Critique [Electronic resource] // Wessex Archaeology. URL: http://www.wessexarch.co.uk/ files/splashimport/wp-content/uploads/2010/04/Firth1995-Three-Facets-of-Maritime-Archaeology140410.pdf (Accessed 12.10.2019).

20. Godwin H., Godwin M. E. British Maglemose Harpoon Sites // Antiquity, 1933, vol. 7(25), pp. 36-48.

\section{References:}

1. UN. (2002) Akty General'noy konferentsii, 31-ya sessiya, Parizh, 15 oktyabrya - 13 noyabrya $2001 \mathrm{~g}$. [Acts of the General Conference, 31st Session, Paris, October 15 November 13, 2001]. Vol. 1. Paris: UN.

2. Okorokov, A.V. (2008) Istoriya otechestvennoy podvodnoy arkheologii [History of Russian underwater archeology]. Moscow: KNORUS.

3. Adams, J. (2003) Ships, Innovation and Social Change: Aspects of Carvel Shipbuilding in Northern Europe 1450-1850. Stockholm: University of Stockholm.

4. Bass, G.F. (2011) The Development of Maritime Archaeology. In: Catsambis, A., Ford, B. \& Hamilton, D.L. (eds) The Oxford Handbook of Maritime Archaeology. Oxford: Oxford University Press. pp. 3-24

5. Bass, G.F. et al. (1967) Cape Gelidonya: A Bronze Age Shipwreck. Transactions of the American Philosophical Society. 57(8). pp. 1-177.

6. Bevan, J. (1996) The Infernal Diver: The Lives of John and Charles Deane, Their Invention of the Diving Helmet, and Its First Application to Salvage, Treasure Hunting, Civil Engineering and Military Uses. London: Submex.

7. Blundell, F.O. (1910) Further Examination of Artificial Islands. Proceedings of the Society of Antiquaries of Scotland. 44. pp. 12-33.

8. Blundell, F.O. (1909) Notices of the examination by means of a diving dress of the artificial island or crannog of Eilean Muireach in the south end of Loch Ness. Proceedings of the Society of Antiquaries of Scotland. 43. pp. 159-164.

9. Burkitt, M.C. (1932) A Maglemose Harpoon dredged up recently from the North Sea. Man. 32. p. 118.

10. Araoz, G. et al. (eds) (2004a) Charter for the Protection and Management of the Archaeological Heritage (1990). In: International Charters for Conservation and Restoration. Vol. 1. München: Lipp GmbH. pp. 104-107.

11. Araoz, G. et al. (eds) (2004b) Charter on the Protection and Management of Underwater Cultural Heritage (1996). In: International Charters for Conservation and Restoration. Vol. 1. München: Lipp GmbH. pp. 122-125.

12. Clark, J.G.D. (1932) The Mesolithic Age in Britain. Cambridge: Cambridge University Press.

13. Clark, J.G.D. (1936) The Mesolithic Settlement of Northern Europe. Cambridge: Cambridge University Press.

14. UNESCO. (2001) Convention on the Protection of the Underwater Cultural Heritage. Paris: UNESCO. pp. 5-14.

15. Crawford, O.G.S. (1927) Lyonesse. Antiquity. 1(01).

16. Dawkins, W.B. (1870) On the Discovery of Flint and Chert under a Submerged Forest in West Somerset. The Journal of the Ethnological Society of London. 2. pp. 141-146.

17. Earle, P. (1980) The Treasure of the Concepción. New York: Viking Press.

18. Fagan, B.M. (2001) Grahame Clark: An Intellectual Life of an Archaeologist. Boulder, Colo.: Westview Press.

19. Firth, A. (2010) Three Facets of Maritime Archaeology: Society, Landscape, and Critique. Wessex Archaeology. 4. [Online] Available from: http://www. wess exarch.co.uk/files/splashimport/wp-content/ uploads/2010/04/Firth-1995-Three-Facets-of-MaritimeArchaeology140410.pdf (Accessed 12.10.2019).

20. Godwin, H. \& Godwin, M.E. (1933) British Maglemose Harpoon Sites. Antiquity. 7(25). pp. 36-48. 
21. Hodder I. Post-processual and interpretive archaeology // Archaeology. The Key Concepts. London: Routledge, 2005, pp. 207-212.

22. Hornell J. Water transport: Origins and early evolution. Cambridge: Cambridge University Press, 2015.

23. Maritime Heritage and Historic Ships: Fourth Report of Session 2004-05. London: The Stationery Office, 2005.

24. Marsden P. Sealed by Time: The Loss and Recovery of the Mary Rose. Portsmouth: The Mary Rose Trust, 2003.

25. Martin C. The Spanish Armada Expedition, 196870 // Marine Archaeology: Proceedings of the Twentythird Symposium of the Colston Research Society Held in the University of Bristol, April 4th to 8th, 1971. London: Butterworth, 1973, pp. 439-461.

26. Martin, C. Full Fathom Five: Wrecks of the Spanish Armada. New York: Viking Press, 1975.

27. Martin, C. La Trinidad Valencera: an Armada Invasion Transport Lost off Donegal. Interim Site Report, 1971-1976 // International Journal of Nautical Archaeology, 1979, vol. 8(1), pp. 13-38.

28. Meide C. The Development of Maritime Archaeology as a Discipline and the Evolving Use of Theory by Maritime Archaeologists. Dissertation Position Paper No. 2 [Electronic Resource] // Academia.edu. URL: https://www. academia.edu/4376520/The_Development_of_Maritime_ Archaeology_as_a_Discipline_and_the_Evolving_Use_of Theory_by_Maritime_Archaeologists (accessed 09.11.2019).

29. Muckelroy K. A Systematic Approach to the Investigation of Scattered Wreck Sites // International Journal of Nautical Archaeology, 1975, vol. 4(2), pp.173190.

30. Muckelroy K. Archeology Under Water: An Atlas of the World's Submerged Sites. New York: McGraw-Hill, 1980.

31. Muckelroy K. Historic Wreck Sites in Britain and Their Environs // International Journal of Nautical Archaeology, 1977, vol. 6(1), pp. 47-57.

32. Muckelroy K. Maritime Archaeology. Cambridge: Cambridge University Press, 1978.

33. Muckelroy K. The Integration of Historical and Archaeological Data Concerning an Historic Wreck Site: the Kennemerland // World Archaeology, 1976, vol. 7(3), pp. 280-290.

34. Naish G. P. B. Forging ahead: an account of the work and aims of the Society for Nautical Research. London: Society for Nautical Research, 1950.

35. Nautical chronicle // The Nautical Magazine: a journal of papers on subjects connected with maritime affairs, 1836, vol. 5, pp. 550-562.

36. Norton T. Stars Beneath the Sea. London: Arrow Books, 1999.

37. Pitt Rivers A. H. Early modes of navigation (1874) // The Evolution of culture, and other essays. Oxford: Clarendon press, 1906, pp. 186-232.

38. Ransley J. Boats are for boys: queering maritime archaeology // World Archaeology, 2005, vol. 37(4), pp. 621629.

39. Reid C. Submerged forests. London : Campridge University Press, 1913.

40. Stanley J. Women at Sea, 1750-today: From Cabin 'Boys' to Captains. Stroud: History Press, 2016.
21. Hodder, I. (2005) Post-processual and interpretive archaeology. In: Renfrew, C. \& Bahn, P. (eds) Archaeology. The Key Concepts. London: Routledge. pp. 207-212.

22. Hornell, J. (2015) Water Transport: Origins and Early Evolution. Cambridge: Cambridge University Press.

23. House of Commons. (2005) Maritime Heritage and Historic Ships: Fourth Report of Session 2004-05. London: The Stationery Office.

24. Marsden, P. (2003) Sealed by Time: The Loss and Recovery of the Mary Rose. Portsmouth: The Mary Rose Trust.

25. Martin, C. (1973) The Spanish Armada Expedition, 1968-70. Marine Archaeology. Proceedings of the Twentythird Symposium of the Colston Research Society Held in the University of Bristol, April 4th to 8th, 1971. London: Butterworth. pp. 439-461.

26. Martin, C. (1975) Full Fathom Five: Wrecks of the Spanish Armada. New York: Viking Press.

27. Martin, C. (1979) La Trinidad Valencera: an Armada Invasion Transport Lost off Donegal. Interim Site Report, 1971-1976. International Journal of Nautical Archaeology. 8(1). pp. 13-38.

28. Meide, C. (2013) The Development of Maritime Archaeology as a Discipline and the Evolving Use of Theory by Maritime Archaeologists. Dissertation Position Paper No. 2. [Online] Available from: https://www.academia. edu/4376520/The_Development_of_Maritime_Archaeology_ as_a_Discipline_and_the_Evolving_Use_of_Theory_by_ Maritime_Archaeologists. (Accessed: 09.11.2019).

29. Muckelroy, K. (1975) A Systematic Approach to the Investigation of Scattered Wreck Sites. International Journal of Nautical Archaeology. 4(2). pp.173-190.

30. Muckelroy, K. (1980) Archeology Under Water: An Atlas of the World's Submerged Sites. New York: McGraw-Hill.

31. Muckelroy, K. (1977) Historic Wreck Sites in Britain and Their Environs. International Journal of Nautical Archaeology. 6(1). pp. 47-57.

32. Muckelroy, K. (1978) Maritime Archaeology. Cambridge: Cambridge University Press.

33. Muckelroy, K. (1976) The Integration of Historical and Archaeological Data Concerning an Historic Wreck Site: The Kennemerland. World Archaeology. 7(3). pp. 280-290.

34. Naish, G.P.B. (1950) Forging ahead: An Account of the Work and Aims of the Society for Nautical Research. London: Society for Nautical Research.

35. The Nautical Magazine: A Journal of Papers on Subjects Connected with Maritime Affairs. (1836) Nautical chronicle. 5. pp. 550-562.

36. Norton, T. (1999) Stars Beneath the Sea. London: Arrow Books

37. Pitt Rivers, A.H. (1906) Early modes of navigation (1874). In: The Evolution of Culture and Other Essays. Oxford: Clarendon Press. pp. 186-232.

38. Ransley, J. (2005) Boats are for boys: queering maritime archaeology. World Archaeology. 37(4). pp. 621629.

39. Reid, C. (1913) Submerged Forests. London: Campridge University Press.

40. Stanley, J. (2016) Women at Sea, 1750-today: From Cabin 'Boys' to Captains. Stroud: History Press.

41. Sténuit, R. (1969) Ireland's Rugged Coast Yields Priceless Relics of the Spanish Armada. National Geographic. 135 (6). pp. 745-777. 
41. Sténuit R. Ireland's Rugged Coast Yields Priceless Relics of the Spanish Armada // National Geographic, 1969, no. 135 (6), pp. 745-777.

42. Torr C. Ancient ships. Cambridge: Cambridge University Press, 1895.

43. Underwater Archaeology, a Nascent Discipline. Paris: UNESCO, 1972.

44. Westerdahl C. Die maritime Kulturlandschaft. Schiffe, Schiffahrtswege, Häfen. Überlegungen zu einem Forschungsansatz // Deutsches Schiffahrtsarchiv, 1986, no. 9, pp. 7-58.

45. Wright E.V. The Bronze Age Boats of North Ferriby, Yorkshire // Expedition, 1971, vol. 16, pp. 3-14.

46. Wright E. V., Churchill D. M. The boats from North Ferriby, Yorkshire, England, with a review of the origins of the sewn boats of the Bronze Age // Proceedings of the Prehistoric Society. Cambridge : Cambridge University Press, 1965, pp. 1-24.
42. Torr, C. (1895) Ancient Ships. Cambridge: Cambridge University Press.

43. UNESCO. (1972) Underwater Archaeology, a Nascent Discipline. Paris: UNESCO.

44. Westerdahl, C. (1986) Die maritime Kulturlandschaft. Schiffe, Schiffahrtswege, Häfen. Überlegungen $\mathrm{zu}$ einem Forschungsansatz. Deutsches Schiffahrtsarchiv. 9. pp. 7-58.

45. Wright, E.V. (1971) The Bronze Age Boats of North Ferriby, Yorkshire. Expedition. 16. pp. 3-14.

46. Wright, E.V. \& Churchill, D.M. (1965) The boats from North Ferriby, Yorkshire, England, with a review of the origins of the sewn boats of the Bronze Age. Proceedings of the Prehistoric Society. Cambridge: Cambridge University Press. pp. 1-24.

Полная библиографическая ссылка на статью:

Николаев, И. Р. Морское культурное наследие: история становления и развития понятия на примере Великобритании / И. Р. Николаев // Наследие веков. - 2020. - № 1. - С. 26-35. DOI: 10.36343/SB.2020.21.1.002

Full bibliographic reference to the article:

Nikolaev, I. R. (2020) Maritime Cultural Heritage: The History of the Formation and Development of the Concept on the Example of Great Britain. Nasledie vekov - Heritage of Centuries. 1. pp. 26-35. (In Russian). DOI: 10.36343/SB.2020.21.1.002 